\title{
Analysis of Business Internal Factors that Impact the profit of IT Entrepreneurship
}

\author{
Rajib Kumar Roy ${ }^{1}$, Dr. R. Duraipandian² \\ ${ }^{1} \mathrm{PhD}$. Scholar, School of Commerce \& Management, Garden City, University, Bangalore. \\ ${ }^{2}$ Professor \& Research Supervisor, School of Commerce \& Management, Garden City, University, Bangalore. \\ Email: ${ }^{1}$ racehorseind@gmail.com, ${ }^{2}$ duraipandian.r@gardencity.university.
}

\begin{abstract}
the aim of this study is to find out the impact of business internal factors towards the business profit for IT entrepreneurships in Bangalore. We have taken the sample size from 200 companies of Bangalore. We have undertaken the internal factors like IT management skill, organization culture, leadership, project implementation experience, technical, marketing, business cash flow, physical asset, HR function, organization maturity into the consideration. We have taken the business profit and business profit as measurement of success factors for the business. During study it was identified that certain business internal factors i.e. organizational culture, business leader's skill, technical skill, marketing skill, organization maturity and cash flow has significant impact on business success. Whereas other factors social acceptance of business, social culture, supply of local workforce, demography, business location, climate, law and order, corruption has no impact of significance on IT entrepreneurship's profit.
\end{abstract}

Keywords

Business Internal Factor, Business Profit, Dependent Variable

Article Received: 04 November 2020, Revised: 25 November 2020, Accepted: 19 December 2020

\section{Introduction}

In India or globally and initiation of business was traditionally considered to be the domain of scholarly challenged individuals or the result of natural inheritance within business communities. Casually we term it as "own business "and professionally we name it as "Entrepreneurship". Passionate individuals either independently or jointly start a venture to follow their dream of making something BIG. And research shows almost 80$90 \%$ of such "new venture" runs in loss and fail to fulfill their business objective. The five phases of entrepreneurship are idea generation, required skill and risk assessment, creation of business strategy and plan, allocation of the resource as stakeholder of business entities, creation and exchange of product with target market. During initial phase of idea development and risk assessment it is absolute priority to understand the SWOT of proposed business and market analysis to identify the strength of the idea.

Business environment or business ecosystem has two types of factors, namely internal and external. Internal factors can be considered as controlled factors as they are business inside and external factors can be considered as uncontrollable factors as they are external factors. Business internal factors can be reshaped and aligned to handle any negative impact from external factors and/or to leverage or exploit the business eco system condition for maximum benefits.

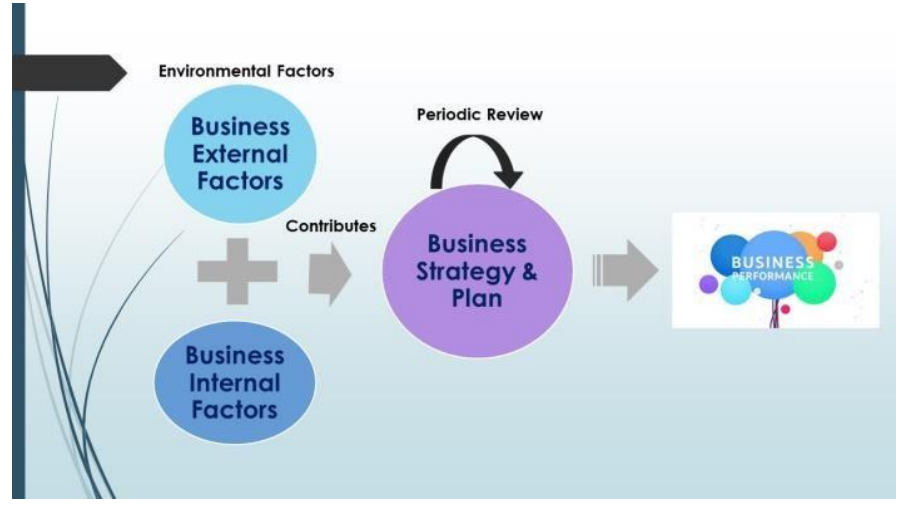

Fig 1: Contribution of environmental factors

Every entrepreneur should have a very close look at the internal factors which has more impact towards the success of the business. By understanding the internal factors entrepreneurs can have better control over the business.

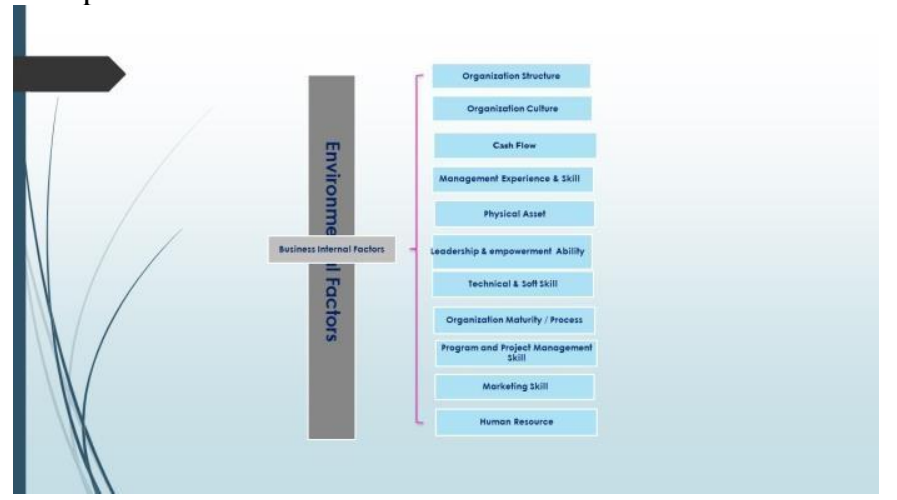

Fig 2: Business internal factors 


\section{Literature review}

While understanding the factors which will have impact on business performance and success, we have undertaken the theories related to Economic entrepreneurship, entrepreneurship theories related to the Psychology of entrepreneurs, Sociological entrepreneurship, theories related to Anthropological entrepreneurship, new business motive which is Opportunity-Based entrepreneurship, and ResourceBased entrepreneurship.

The economic theory of entrepreneurship is having the mix of classical, neo-classical and Austrian market process. These theories explore the economic factors that enhance entrepreneurial behaviors.

In 1817 Ricardo and in 1776 Smith shown the classical theories that explained the virtues of free trade, business specialization and competitive positions of entrepreneurships. This theory was a outcome of the britain's industrial revolution in mid 1700 and which lased almost until 1830 s. In this theory the role of entrepreneur in context of industrial production, manufacturing and distribution effectiveness was portrayed in business competitive platform (Say, 1803). It was also shown that in classic format for entrepreneurship theories the modes of production were based on land, capital and labor.

In 2006 Murphy, lieo and Welsch described the neo- classical movement in entrepreneurship, this model was a outcome of the critical review of classical model and shown the economic phenomenon which can relegate the instance of pure exchange which can also be the reflection of optimal ratio. It was also shown that any economic system is a combinational factor of participants who want to exchange, the occurrence of exchanges and the overall "factor of impact" will result in exchange of potential actors of market. In 1934 Joseph Aloi Schumpeter (1934) described out a platform of theory where human action plays major role in the context of an economy of any country or system. Schumpeter described that the entrepreneurship as a driver of market-based systems, it is important function of an enterprise which intend to create something new which resulted in processes that served as impulses for the motion of market economy.

In 1961, McClelland described the need of achievement for any individual, workers or entrepreneurs, it was also shown that the contends and attitude for the people who desire to achieve in order for their inner accomplishment and the same has a strong impact on their business, goal, vision and mission.

"Locus of control", which was started by Rotter in 1966, which shown that the degree of impact which individual believe that the control of success, good, bad is in the control of destiny. Which was further elaborated to internal and external. The believe of doing good or bad will result in good for bad for any individual or people in general. Which also has an impact over business.

Landstrom in 1998 which was a starting of modern era of IT and technology, shown level of analysis in psychological theories is the individual who wanted to create new product or services in a given economy or platform. During establishing this theory, he emphasizes the personal characteristics to define the structure and mode of entrepreneurship. The concept of psychology state and attitude was described for entrepreneurs and nonEntrepreneurs. The concept was more elaborated to the understanding of successful and unsuccessful entrepreneurs in multiple ways.

In 2001, while describing the modern platform of psychodynamic model Kets de Vries described the relationship of self-employment, "disturbed childhood". In this concept, the disturbance in childhood where people will have lack of confidence / self-esteem due to lack of security, physical and mental abuse in earlier age. This result in low power of empowerment and success. The affected individuals become introvert and doesn't express the feeling of tend to desire more for success.

In another theory of risk-taking ability, the self-employed people intend to take more risk to move forward or achieve in their life rather then people who are not self-employed. Selfemployed people are more aligned the generic protocol of social and employment structure and has less ability on innovation.

In 1998, Landstrom and 1991 Reynolds shown the concept of entrepreneurial opportunities through social network and building such potential network which plays major role for successful entrepreneurship. The promotion of trust plays vital role in business shape and success, During the social network building.

In the theory of social entrepreneurship, individual thoughts, their social aligned actions which has strong influence over the outcome of such acceptance from society or network group. The background of entrepreneur has a strong alignment on the entrepreneurial journey. The vision of an entrepreneur is highly corelated with the individual education, family image and culture.

In the concept of entrepreneurship's alignment from anthropology, the human origin, custom and beliefs of communities related to society is analyzed to understand the new venture's success.

In 2003 Baskerville shown that the attitude/behaviors/vision/action, culture of individual affected by the complexities like ethnic race, social, economic, ecological and political factors (described by Mitchell et al in 2002). It was also shown that the cultural difference is having impact over the entrepreneurial behaviors and its success (shown by Norh in 1990 and Shane in 1994).

The cultural practice is having strong potential on entrepreneurial journey, attitude and innovation. The vision and venture creation attitude, risk taking ability is a factor of the cultural outcome.

Peter Drucker and howard shown a theory which is opportunity based and the conceptual behaviors of a entrepreneurship depends upon the exploitation of business opportunities (which was further elaborated by Fiet in 2002 and Shane in 2000).

In this theory the entrepreneur tends to exploit the available opportunities like technology, consumer requirements, and creates ((Drucker, 1985) product of services. Entrepreneurs always look for suitable opportunities where they can make differences and identify the gap to create something new by exploiting the situation.

Stevenson (1990) extends Drucker's opportunity-based construct, he included that the entrepreneurial management 
is the recreation of opportunity without regard to resources currently controlled in the given platform.

In 1999, Aldrich shown that resource-based entrepreneurships are important predictor on opportunitybased business and plays a major role in growth of entrepreneurship. The resource further described as major pillar for any new business, namely financial resource, social resource (platform of consumer) and human resource. In any entrepreneurship once the opportunity is identified, the action from individual exploiting the opportunity depending upon the access and command on capital market, finance and human resource. (Davidson \& Honing, 2003). In the paper IMPACT OF SOCIAL-CULTURAL FACTORS ON ENTREPRENEURS IN INDIA by Ankita Barik, Bhavesh Vanparia, Lal Bihari Barik spoke about the impact of cultural background of a person on entrepreneurship. The environment, the education and the ecosystem of an individual belongs to plays vital role of the success and growth of entrepreneurship. This paper also focused on the other social aspects of an ecosystem like religion, family, financial status, education, and ethics.

This study also brought the public policy, university activities to effective the entrepreneurship program (Lüthje, Christian, and Nikolaus Franke. "The 'making' of an entrepreneur: testing a model of entrepreneurial intent among engineering students at MIT", R\&D Management, vol. 33, No. 2, pp. 135147, 2003. )

The study also did a review on role of teachers and parents to provide personality-profiling exercise to ensure that individuals can identify the entrepreneurship potential (Sharma, Lalit, and Pankaj Madan. "Personality Traits Influencing Youth Entrepreneurship-An Empirical Study in Uttarakhand State, India", ISSN 2251-239X, pp. 6, 2013).

In 2007 Ejaz Ghani William R. Kerr Stephen D. O'Connell worked on In SPATIAL DETERMINANTS OF

ENTREPRENEURSHIP IN INDIA which was published NATIONAL BUREAU OF ECONOMIC RESEARCH

The paper was shown the impact of entrepreneurship on economic growth of India as traditionally india has low rate of new venture creation. The overall weakness of start-ups is changing slowly towards positive direction and post 2000 more new ventures are established which has strong impact on Indian economy. The paper went ahead to analyses the manufacturing and service industry. How education and infrastructure play role in promoting new venture to social platform. The factors which play the role of labor law and impact on entry criteria for the business.

Hypothesis \& Methodology: The aim was to analyze the business internal factors which has impact on IT business performance and success. Following the objective, the below hypothesis was made

Ho: There is no influence of business internal factors on profit of IT entrepreneurship

Ha: There is strong influence of business internal factors on profit of IT entrepreneurship

During the research, confidence level of $95 \%$ is identified from population. It was identified that 200 should be the sample size for analysis. Data collected from senior stakeholder of companies from operation, management, founder groups.

We identified the factors which has influence on entrepreneurships are
- Organization structure defines the hierarchy or organization as per activities, role and operations

- IT Management skill is capabilities of information technology adoption as per market demand

- Organization culture which defines is belief, values, vision, attitude, custom

- $\quad$ Technical skill which defines core technology used towards solution building and operation

- Leadership skill which organizes the available resource and arrange to reach objective

- $\quad$ Project implementation experience is the capability of understanding business of customer requirements and adoption of right development process

- $\quad$ Marketing skill to promote, sale and have strong customer orientation

- $\quad$ Cash flow to ensure that business doesn't run out of fuel, all operations are paid on time

- $\quad$ Physical asset is the capital asset of a company i.e factory, machines, equipment, offices etc.

- Human Resource is the department of intellectual human asset where human is recruited to finish projects/job

- Organization maturity to ensure that entrepreneurship's readiness towards capability building and handle people, process and technology adoption \& change

been identified to collect the data. Likert scale-based survey is conducted through telephonic and email communication. Data collected using MS Excel and analysis processed we used SPSS.

\section{Research Methodology}

During the data collection we have taken data from 200 senior business stakeholder individuals of IT entrepreneurship companies. The position of the stakeholder's play major role in our analysis. We have chosen only senior stakeholder of the business as they have more visibility, understanding and control over formation of business, operation / execution. So, we have taken people from business, consulting, Human resource and operation, solution delivery, head of IT. cadre/profession

\begin{tabular}{|l|l|l|l|l|}
\hline & $\begin{array}{l}\text { Freque } \\
\text { ncy }\end{array}$ & $\begin{array}{l}\text { Perce } \\
\text { nt }\end{array}$ & $\begin{array}{l}\text { Valid } \\
\text { Percent }\end{array}$ & $\begin{array}{l}\text { Cumulat } \\
\text { ive } \\
\text { Percent }\end{array}$ \\
\hline $\begin{array}{l}\text { Business head } \\
\text { Consulting } \\
\text { head }\end{array}$ & 17 & 8.5 & 8.5 & 8.5 \\
Hr head & 28 & 14.0 & 14.0 & 26.5 \\
$\begin{array}{l}\text { Senior } \\
\text { Vali delivery } \\
\text { manager } \\
\begin{array}{l}\text { Chief Business } \\
\text { manager }\end{array}\end{array}$ & 36 & 18.0 & 18.0 & 66.0 \\
Global IT lead & 49 & 24.5 & 24.5 & 90.5 \\
Director & 19 & 9.5 & 9.5 & 100.0 \\
Total & 200 & 100.0 & 100.0 & \\
\hline
\end{tabular}

Table: 1: Professional level of the participants 
When we checked the overall qualification of the professionals which gave us a good level of confidence as higher and medium qualification has a good distribution.

\section{Qualification}

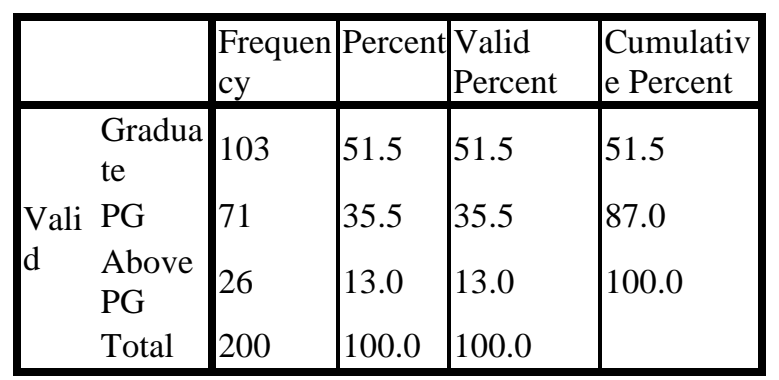

Table: 2: Qualification level of the participants

During the data collection, we have taken 11 business inter factors which we have shown above and We have taken two dependent variables namely

DV: Business profit grown for last 3 years

The dependent variables are tested against 11 parameters separately to identify if there is a significant relationship between them. The overall goal of the multiple regression is to validate if there are some factors which has more significant over others on companies' profitability.

Ever traditional business, we consider business profit as measurement of performance and core fundamental of a business health.

In our first analysis, we did the significance analysis of 11 internal factors on Business profit (DV).

\section{Model Summary}

\begin{tabular}{|c|c|c|c|c|}
\hline Model & $\mathrm{R}$ & R Square & $\begin{array}{l}\text { Adjusted } \\
\text { Square }\end{array}$ & $\begin{array}{l}\text { RStd. Error of } \\
\text { the Estimate }\end{array}$ \\
\hline$\overline{1}$ & $.957^{\mathrm{a}}$ & .915 & .910 & .316 \\
\hline
\end{tabular}

Table: 3: Model summary

\section{ANOVA ${ }^{a}$}

\begin{tabular}{|c|c|c|c|c|c|c|}
\hline Mod & & $\begin{array}{l}\text { Sum } \\
\text { Squares }\end{array}$ & $\mathrm{f}$ & $\begin{array}{l}\text { Mean } \\
\text { Square }\end{array}$ & $\mathrm{F}$ & Sig. \\
\hline \multirow[t]{3}{*}{1} & $\begin{array}{l}\text { Regressio } \\
\mathrm{n}\end{array}$ & 203.088 & 11 & 18.463 & $\begin{array}{l}184.75 \\
2\end{array}$ & $.000^{\mathrm{b}}$ \\
\hline & Residual & 18.787 & 188 & .100 & & \\
\hline & Total & 221.875 & 199 & & & \\
\hline
\end{tabular}

Table: 4: Analysis of variance of 11 business internal factors

R-squared measures the proportion of the variation in our dependent variable (DV) by our independent variables for a linear regression model. Adjusted R-squared adjusts the statistic based on the number of independent variables in the model.

When we did regression analysis, we found the below result.
Tests of Between-Subjects Effects

Dependent Variable: DV Has business profit has been increasing over the past three years

\begin{tabular}{|c|c|c|c|c|c|}
\hline Source & $\begin{array}{l}\text { Type II } \\
\text { Sum of } \\
\text { Squares }\end{array}$ & df & $\begin{array}{l}\text { Mean } \\
\text { Square }\end{array}$ & $\mathrm{F}$ & Sig. \\
\hline Corrected Model & $203.088^{\mathrm{a}}$ & 11 & 18.463 & $\begin{array}{l}184.75 \\
2\end{array}$ & .000 \\
\hline Intercept & .058 & 1 & .058 & .583 & .446 \\
\hline $\begin{array}{l}\text { Organization } \\
\text { structure }\end{array}$ & .004 & 1 & .004 & .037 & .847 \\
\hline $\begin{array}{l}\text { IT Management } \\
\text { skills }\end{array}$ & .008 & 1 & .008 & .081 & .776 \\
\hline $\begin{array}{l}\text { Organization } \\
\text { Culture }\end{array}$ & 90.799 & 1 & 90.799 & $\begin{array}{l}908.61 \\
6\end{array} \mid$ & .000 \\
\hline Leadership Skill & .660 & 1 & .660 & 6.607 & .011 \\
\hline $\begin{array}{l}\text { Project } \\
\text { implementation } \\
\text { experience }\end{array}$ & .148 & 1 & .148 & 1.477 & .226 \\
\hline Technical Skill & .750 & 1 & .750 & 7.501 & .007 \\
\hline Marketing skill & .647 & 1 & .647 & 6.472 & .012 \\
\hline $\begin{array}{l}\text { Impact } \\
\text { Cashflow }\end{array}$ & .626 & 1 & .626 & 6.269 & .013 \\
\hline Physical Asset & .006 & 1 & .006 & .059 & .809 \\
\hline Human Resource & .046 & 1 & .046 & .464 & .497 \\
\hline $\begin{array}{l}\text { Organization } \\
\text { Maturity }\end{array}$ & .610 & 1 & .610 & 6.108 & .014 \\
\hline Error & 18.787 & 188 & .100 & & \\
\hline Total & 2923.000 & 200 & & & \\
\hline Corrected Total & 221.875 & 199 & & & \\
\hline
\end{tabular}

Table: 5: Coefficient of 11 business internal factors on business profit

In the above Anova and regression table the p-value is less than 0.05 for the bold values indicating that it is significant so we conclude that there is influence of business internal factors on business profit over the past three years.

\section{Result and discussion}

Initially we created two hypotheses

Ho: There is no influence of business internal factors on Profit of IT entrepreneurship

Ha: There is strong influence of internal factors on Profit of IT entrepreneurship

Data undertaken during analysis

Dependent variable (DV): Business profit grown for last 3 years

The result of ANOVA result is shown in table 4

$\mathrm{R}$ square is shown in table 3 . Which is the ratio of the regression sum to the total sum: $203.088 / 221.875=0.915$. 203.088 is the proportion of the total scattering. 221.875 is the total scattering

We have computed the F test to check suitability of the

prediction. For the given analytic model the $\mathrm{F}$ ratio is 184.752. The computed result in a p-value is 0.000 . Since the p-value of $0.000<0.005$, the null hypothesis should be rejected. The null hypothesis Ho says, that There is no influence of business internal factors on performance of IT entrepreneurship. 
We have also shown the impact of single independent variable on DV.

The analysis shows that the factors which has most significant impact towards business profit as they have $<0.05 \mathrm{p}$-value

$\begin{array}{ll}\text { 1. } & \text { Organization culture } \\ \text { 2. } & \text { Technical Skill } \\ \text { 3. } & \text { Leadership skill } \\ \text { 4. } & \text { Marketing } \\ \text { 5. } & \text { Cash flow } \\ \text { 6. } & \text { Organization maturity }\end{array}$

The above result shows that if any IT entrepreneurship grow up building stronger value, vision, leadership to create robust technical skill for solution development and marketing will be successful towards profitability.

And hence the alternate hypothesis can be established as Ha: There is strong influence of internal factors on Profit of IT entrepreneurship

\section{Conclusion}

The success of IT entrepreneurship depends upon multiple factors. Profit is a best way to measure the success and performance of a business. New age leaders should put more effect towards the development of organizations with higher value, vision and the written or unwritten custom and belief. Leader's responsibility to establish situation skill to build the capability with the available technical skill and market the capability. Efficient usage of cash flow determines parameters of organization maturity towards future growth. During the business idea development phase entrepreneur should collect all parameters towards the identified factors and measure accordingly.

\section{References}

[1] International Journal of Advanced Research in Engineering and Technology (IJARET) Volume 9, Issue 6, NovemberDecember 2018, pp. 236-240, Article ID: IJARET_09_06_025 Available online at http://www.iaeme.com/IJARET/issues.asp ?JType $=$ IJARET $\&$ VType $=9 \&$ IType $=6$ ISSN Print: 0976-6480 and ISSN Online: 0976-6499

[2] IOSR Journal of Business and Management (IOSR-JBM) e-ISSN: 2278- 487X, p-ISSN: 2319-7668. Volume 16, Issue 5. Ver. III (May. 2014), PP 48-50

[3] A Study on Impact Of Subjective Norms On Entrepreneurial Intention Among The Business Students In Bangalore by J.Krithika1 , Dr.B.Venkatachalam2

[4] https://www.forentrepreneurs.com/whystartups-fail/
[5] https://discuss.analyticsvidhya.com/t/differ ence-between-r-square-and-adjusted-rsquare $/ 264 / 3$

[6] Why Startups Fail And What You Can Do To Beat The Odds Kindle Edition by George Meszaros

[7] All In Startup: Launching a New Idea When Everything Is on the Line Kindle Edition by Diana Kander

[8] Why Startups Fail: And How Yours Can Succeed by David Feinleib

[9] http://www.forentrepreneurs.com/whystartups-fail/

[10] Technology Innovation Management Review, January 2018 (Volume 8, Issue 1)

[11] Technology Entrepreneurship in Emerging Markets: An Exploration of Entrepreneurial Models Prevalent in India by Shiv S Tripathi and Mita Brahma

[12] IMPACT OF SOCIAL-CULTURAL FACTORS ON ENTREPRENEURS IN INDIA by Ankita Barik, Bhavesh Vanparia , Lal Bihari Barik

[13] SPATIAL DETERMINANTS OF ENTREPRENEURSHIP IN INDIA Ejaz Ghani William R. Kerr Stephen D. O'Connell

[14] NATIONAL BUREAU OF ECONOMIC RESEARCH 1050 Massachusetts Avenue Cambridge, MA 02138https://www.entrepreneur.com/articl $\mathrm{e} / 236999$

[15] Technology Entrepreneurship Ecosystem in India: Findings from a Survey by Ruchita Gupta1 ,Karuna Jain1 ,AnandKusre2, Kirankumar S. Momaya of National Institute of Industrial Engineering

(NITIE),https://www.cbinsights.com/resea rch/startup-failure-reasonstop/https://www.spiderg.com/8accounting-problems-facedstartups/https://www.forbes.com/sites/supa rnadutt/2017/05/18/startups-in-india-faildue-lack-of-innovation-according-to-anew-ibm-study/\#60463065657b 
[16] https://www.moneyweb.co.za/mybusiness/ why-do-70-to-80-of-small-businesses-failwithin-five-years/

[17] National Policy on Skill Development and Entrepreneurship ReportThe theory of entrepreneurship modelStart up policy (2015-2020) by government of Karnatakahttps://repository.up.ac.za/bitstre am/handle/2263/28708/Complete.pdf?sequ ence $=9$

[18] IMPACT OF MOTIVATIONAL FACTORS OF NASCENT ENTREPRENEURS ON BUSINESS SURVIVING SUCCESS by Christoph Ernst Wilken Kisker Submitted for the Doctoral Degree in Management Science UNIVERSITY OF LATVIA

[19] https://edge.alluremedia.com.au/uploads/b usinessinsider/2015/07/Fear-of-failurearound-the-world.jpg https://www.goglobe.com/blog/startups/

http://www.thehindubusinessline.com/info -tech/90-startups-in-india-fail-within-5years-ibm/article9704251.ece

[20] Comparing the Entrepreneurial Ecosystems for Technology Startups in Bangalore and Hyderabad, India by $\mathrm{M} \mathrm{H}$ Bala Subrahmanya Technology Innovation Management Review July 2017 (Volume 7, Issue 7)

[21] Licensee MDPI, Basel, Switzerland. This article is an open access article distributed under the terms and conditions of the Creative Commons Attribution (CC BY) license (http://creativecommons.org/licenses/by/4. 0/Factors Affecting Entrepreneurship and Business Sustainabilityby Ana Tur-Porcar 1,* ID , Norat Roig-Tierno 2,3 and Anna Llorca Mestre 4

[22] Entrepreneurship theories and Empirical research: A Summary Review of the Literature by Kwabena Nkansah Simpeh, European Journal of Business and Management www.iiste.org ISSN 22221905 (Paper) ISSN 2222-2839 (Online), Vol 3, No.6, 2011
[23] Building a Concept of Entrepreneurial Control Hanif Hanif, Abdulah Rakhman, Muhammad Nurkholis, TEM Journal. Volume 8, Issue 4, Pages 1198-1206, ISSN 2217-8309, DOI: 10.18421/TEM84- 13, November 2019

[24] Factors Influencing Project Success: A Qualitative Research by Nermina Durmic, TEM Journal. Volume 9, Issue 3, Pages 1011-1020, ISSN 2217-8309, DOI: 10.18421/TEM93-24, August 2020.

[25] Startup innovation capability from a dynamic capability-based view: A literature review and conceptual framework by Samia El Hanchi1 , Lamia Kerzazi2

[26] The relationship between a comprehensive strategic approach and small business performance Ralph I. Williams Jr.1, Scott C. Manley2, Joshua R. Aaron3, Francis Daniel4 in journal of small business strategy

[27] An Everlasting Battle between Theoretical Knowledge and Practical Skills? The Joint Impact of Education and Professional Experience on Entrepreneurial Success by Agnieszka Kurczewska, Wirginia Doryń, Dorota Wawrzyniak, EBER.2020.080212, 2020, Vol. 8, No. 2

[28] Entrepreneurial Strategy Stimulating Value Creation: Conceptual Findings and Some Empirical Tests by Wojciech Dyduch, EE concept recognizes the importance of territorial environments for productive, 2019, Vol. 7, No. 3

[29] The Performance of High-Growers and Regional Entrepreneurial Ecosystems: A Research Framework by Marta Gancarczyk, EBER.2019.070306, 2019, Vol. 7, No. 3

[30] The Four Models of Corporate Entrepreneurship By Robert C. Wolcott and Michael J. Lippitz

[31] (See, for instance, R. Gulati (introduction), "How CEOs Manage Growth Agendas," Harvard Business Review 82 (JulyAugust, 2004): 124-132.)(Corporate Strategy Board, "Stall Points: Barriers to 
Growth for the Large Corporate Enterprise" (Washington, D.C.: Corporate Strategy Board, 1998).

[32] Entrepreneurial Mindset: A Synthetic Literature Review by Christiane Naumann, EBER.2017.050308 2017, Vol. 5, No. 3

[33] Analysing the Role of Framework Conditions Influencing International Entrepreneurial Opportunity Identification Process by Yonni Angel Cuero Acosta, Richard Adu-Gyamfi, Md. Noor Un Nabi, Utz Dornberger, EBER.2017.050301, 2017, Vol. 5, No. 3

[34] The Concept of Technological Entrepreneurship: The Example of Business Implementation by Ewa Badzińska, EBER.2016.040305, 2016, Vol. 4, No. 3

[35] The role of ethical behavior and entrepreneurial leadership to improve organizational performance Anak Agung Dwi Widyani, Nengah Landra, Nengah Sudja, Mateus Ximenes \& I Wayan Gde Sarmawa, ISSN: (Print) 2331-1975 (Online) Journal homepage, Cogent Business \& Management

[36] Factors that Positively Influence the Initiation of a Business by Alice Reissová, Jana Šimsová, Kateřina Kovářová, Radek Šimanovský, TEM Journal. Volume 8, Issue 2, Pages 486-491, ISSN 2217-8309, DOI: 10.18421/TEM82-23, May 2019.www.thehindubusinessline.comhttps: //www.entrepreneur.com/ \& https://www.cbinsights.com/ 